\title{
Some effects of gasoline and diesel mixtures on partially premixed combustion and comparison with the practical fuels gasoline and diesel in a compression ignition engine
}

Proc IMechE Part D:

J Automobile Engineering

226(9) 1259-1270

(c) IMechE 2012

Reprints and permissions:

sagepub.co.uk/journalsPermissions.nav DOI: $10.1177 / 0954407012440075$

pid.sagepub.com

@SAGE

\author{
Hyun Woo Won ${ }^{1,2}$, Heinz Pitsch', Nigel Tait ${ }^{2}$ and Gautam Kalghatgi ${ }^{3}$
}

\begin{abstract}
If fuels that are more resistant to autoignition are injected near top dead centre in compression ignition engines, they ignite much later than diesel fuel does, and combustion occurs when the fuel and air have had more chance to mix. This helps to reduce nitrogen oxide and smoke emissions. Moreover, this can be achieved at much lower injection pressures than for a diesel fuel. However, it is preferable to have fuels with a lower research octane number than those of commonly available gasolines, because this makes low-load operation easier while retaining the advantages at higher loads. A practical approach to making such fuels is to blend the gasoline and diesel fuel available in the market. Such fuel blends have a wide volatility range since they contain high-boiling-point components from the diesel but have a lower research octane number than that of the gasoline used but have a much longer ignition delay than that of the diesel fuel. This work describes the results of running a single-cylinder diesel engine on three such fuel blends. The engine could be run on such blends with extremely low smoke and low nitrogen oxide emissions at speeds of up to $4000 \mathrm{r} / \mathrm{min}$ and loads (indicated mean effective pressures) of up to 10 bar with an injection pressure of only 400 bar. The smoke levels at comparable nitrogen oxide levels were extremely high with diesel fuel in these conditions, even with an injection pressure of I 100 bar. The engine could also be run at near-idle conditions on these blends but with higher hydrocarbon and carbon monoxide emissions but much lower nitrogen oxide emissions and maximum pressure rise rate compared with those of the diesel fuel. The wider volatility range might be of benefit in avoiding over-mixing and over-leaning, which could lead to poor combustion stability. The paper also considers the trade-offs between the nitrogen oxide, smoke, hydrocarbon and carbon monoxide emissions and the maximum pressure rise rate and discusses approaches to optimise this type of combustion.
\end{abstract}

\section{Keywords}

Sufficiently premixed compression ignition, high-octane-number fuel, partially premixed compression ignition, autoignition, compression ignition engine, mixture of gasoline and diesel

Date received: I5 September 20I I; accepted: 27 January 2012

\section{Introduction}

In a conventional compression ignition (CI) engine, air is gradually drawn into the fuel spray from the surrounding area. The ignition delay period is short, and so combustion starts before the fuel has thoroughly mixed with the air. Consequently, combustion takes place in mixture packets that are overly rich, resulting in smoke, ${ }^{1}$ while combustion in stoichiometric mixture packets that are inevitably formed with further mixing with air causes high levels of nitrogen oxides $\left(\mathrm{NO}_{x}\right)^{2}$ When conventional diesel fuel is used, it is practically impossible to avoid fuel-rich and stoichiometric pockets completely. If a fuel ignites much later than diesel fuel and combustion occurs when the fuel and air have had

'Institute of Combustion Technology, RWTH Aachen University, Aachen, Germany

${ }^{2}$ Shell Global Solutions (UK), Chester, UK

${ }^{3}$ Saudi Aramco, Dhahran, Saudi Arabia

\section{Corresponding author:}

Hyun Woo Won, Shell Global Solutions (UK), Shell Technology Centre Thornton, PO Box I, Chester CHI 3SH, UK.

Email: hyun-woo.won@shell.com 
more chance to mix, both pollutants could be reduced simultaneously without resulting in the well-known soot- $\mathrm{NO}_{x}$ trade-off. If the same amount of gasoline is injected very early in the cycle in the same conditions, i.e. with fully premixed ${ }^{3}$ homogeneous charge compression ignition (HCCI) conditions, ignition might not occur at all. Thus inhomogeneity is essential for combustion to happen; the fuel and air should be sufficiently premixed but must not be fully premixed. This mixture stratification, ${ }^{4-7}$ which enables control of the phasing of combustion through injection timing, is easily achieved simply by relatively late injection compared with HCCI. Much higher loads can be achieved at low smoke and $\mathrm{NO}_{x}$ levels with gasoline compared with diesel while retaining control over combustion. However, partially premixed compression ignition (PPCI) operation also leads to higher carbon monoxide (CO) and hydrocarbon (HC) emissions at low loads and higher heat release rates (HRRs) at high loads. These problems can be significantly alleviated by managing the mixing through injector design and injection strategies (e.g. multiple injection). Larger injector hole diameters and lower injection pressures might be better for gasoline fuels because it helps to increase stratification and to avoid over-mixing and over-leaning. Such fuels, with a lower octane number than that of today's gasoline but with more relaxed volatility specifications might offer benefits in terms of better fuel manufacturing efficiencies. Low-NO ${ }_{x}$, low-smoke and high-efficiency CI combustion is likely to benefit from fuels with a lower cetane number $(\mathrm{CN})$ than those of the current diesels and with lower octane numbers and lower volatilities than those of current gasoline, enabling lower injection pressures using enlarged nozzle orifices compared with the situation in current CI engines. There appears to be much incentive and also scope to develop such engine combustion systems. More recently, groups at Lund University $^{8,9}$ and the University of WisconsinMadison $^{10}$ have demonstrated that heavy-duty CI engines can be run on gasoline as well as on ethanol ${ }^{8,9}$ with very high efficiency and very low $\mathrm{NO}_{x}$ and smoke emissions. Weall and Collings have also demonstrated the benefits of low-reactivity fuels by studying mixtures of gasoline and diesel ${ }^{11}$ and have also addressed the issues arising from running a CI engine on gasoline at low loads and low speeds. ${ }^{12}$

Current European gasoline, with a minimum research octane number (RON) of 95, is too resistant to autoignition to allow the engine to run in the CI mode at low loads and at high speeds and also, in many cases, with sufficient exhaust gas recirculation (EGR) to control the $\mathrm{NO}_{x}$ emissions. A practical way of reducing the RON would be to blend diesel fuel with gasoline. Such fuel blends have a wide volatility range since they contain high-boiling-point components from the diesel but have lower RONs than that of the gasoline used but have much longer ignition delays than that of the diesel fuel. This work describes the results of running a single-cylinder diesel engine on three such fuel blends. It is important to avoid over-mixing the fuel with oxygen in low-load conditions; the use of lower injection pressures and higher injector flow rates helps to achieve this. At the same time, it is also important to avoid vapour lock in the injection system with highoctane-number fuels which have low boiling points. The wider volatility range of the gasoline-diesel blends might help to achieve these goals. With fuels which have long ignition delays, a lower injection pressure results in better combustion stability and significantly lower $\mathrm{HC}$ and $\mathrm{CO}$ emissions without compromising the $\mathrm{NO}_{x}$ or smoke emissions. The engine could be run on such blends with extremely low smoke and low $\mathrm{NO}_{x}$ levels at speeds of up to $4000 \mathrm{r} / \mathrm{min}$ and loads (indicated mean effective pressures (IMEP)) of up to 10 bar with an injection pressure of only 400 bar. The smoke level at comparable $\mathrm{NO}_{x}$ levels was extremely high with diesel fuel in these conditions, even with an injection pressure of 1100 bar. The engine could also be run at low loads and speeds including near-idle conditions on these blends but with higher $\mathrm{HC}$ and $\mathrm{CO}$ emissions but much lower $\mathrm{NO}_{x}$ emissions and a maximum pressure rise rate (MPRR) compared with those of the diesel fuel.

\section{Experimental set-up}

\section{Engine}

The experiments were performed on a 0.5371 singlecylinder research engine with a compression ratio of 15.9:1. The specifications of the single-cylinder engine are given in Table 1 . All experiments were made with coolant and oil temperatures at $90^{\circ} \mathrm{C}$ and the inlet air temperature was kept at $60^{\circ} \mathrm{C}$. Fuel was injected via a Bosch seven-hole injector, with an injector cone angle of $153^{\circ}$, fed by an independent fuel supply rig. The injectors are controlled using an IAV GmbH injection controller to maintain a constant injection pressure, injection timing and IMEP. An external air compressor was used to simulate boosted conditions. When EGR was introduced, the exhaust back pressure was set 0.2 bar higher than the inlet manifold air pressure, and the recirculated gases were cooled using an external cooling circuit to the same temperature as the inlet air, i.e. $60^{\circ} \mathrm{C}$. The in-cylinder pressure was measured with a

Table I. The specifications of the single-cylinder engine.

\begin{tabular}{ll}
\hline Engine & Single-cylinder engine \\
\hline Displacement volume (I/cylinder) & 0.537 \\
Bore $(\mathrm{mm})$ & 88 \\
Stroke $(\mathrm{mm})$ & 88.3 \\
Connecting-rod length $(\mathrm{mm})$ & 149 \\
Compression ratio & $15.9: 1$ \\
Intake valve open $(\operatorname{deg} C A)$ & 362 \\
Intake valve closed $(\operatorname{deg} C A)$ & 595 \\
Exhaust valve open (deg CA) & 143 \\
Exhaust valve closed (deg CA) & 385 \\
\hline
\end{tabular}

CA: crank angle. 
water-cooled pressure transducer (Kistler 6041A). The emissions and inlet carbon dioxide $\left(\mathrm{CO}_{2}\right)$ level were measured using a Horiba MEXA-9500H system, and soot was measured using an AVL 415 smoke meter. After a stabilisation period, the emissions were logged once per second for $60 \mathrm{~s}$ and the averages of those 60 recordings are presented in this paper. At the same time, the in-cylinder pressure was recorded for 250 cycles.

\section{Nozzles}

Two nozzles are used in this study. Nozzle 01 is a standard nozzle with a $0.13 \mathrm{~mm}$ orifice diameter for the engine, and nozzle 02 is designed for high-octanenumber fuels with a $0.17 \mathrm{~mm}$ nominal orifice diameter and higher flow number than that of nozzle 1. Figure 1 shows the flow rates of each nozzle with different injection pressures and durations. Clearly the flow rate changes do not correspond to the external orifice diameters quoted above, which were measured using an electron microscope. Nozzle 02 was made by first laser welding the holes of a duplicate nozzle 01 , next drilling the larger hole size and then honing it. There are clearly factors (perhaps cavitation) that affect the discharge coefficient of this nozzle. Otherwise the flow rate would have increased by a factor which is the square of the external nozzle diameters quoted above.

\section{Fuels}

The conventional diesel has a lower RON than that of the currently available gasoline fuel. Correspondingly, the currently available gasoline fuel has a lower $\mathrm{CN}$ than that of the currently available diesel fuel. A blend

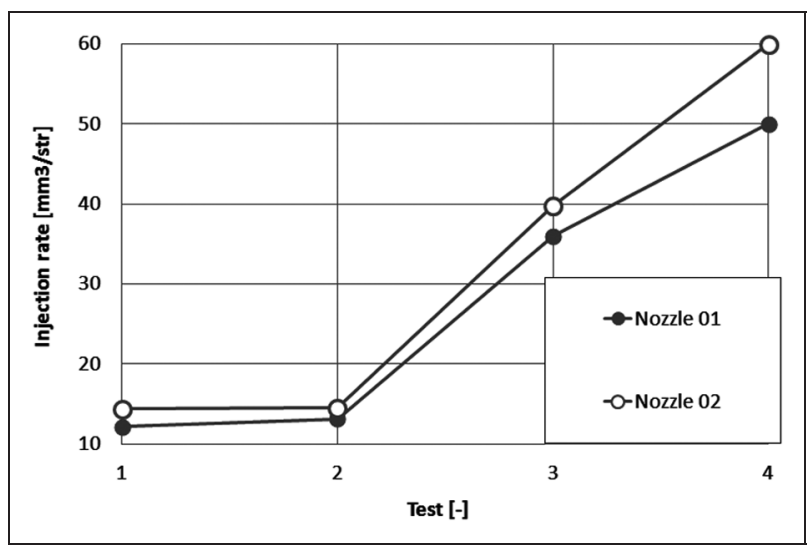

Figure I. Injection flow rates for two nozzles at different injection pressures and injection durations (test I has an injection pressure of 250 bar and an injection duration of $1220 \mu \mathrm{s}$; test 2 has an injection pressure of 400 bar and an injection duration of $800 \mu s$; test 3 has an injection pressure of 600 bar and an injection duration of $1060 \mu$ s; test 4 has an injection pressure of 600 bar and an injection duration of $1500 \mu \mathrm{s})$. of currently available gasoline fuel and diesel fuel yields a fuel composition having both a lower octane number and a lower $\mathrm{CN}$ than the corresponding values for individual gasoline fuel and diesel fuel respectively, which is especially suitable for PPCI engines. The ignition qualities of the blended fuels can be varied as needed to meet the requirements of the PPCI engine. A commercial European gasoline fuel and three different blended fuels are used in this study and compared with a standard European diesel fuel. The three blended fuels are GD10 (90 vol \% of $95 \mathrm{RON}$ European gasoline and $10 \mathrm{vol} \%$ of $56 \mathrm{CN}$ European diesel fuel), GD20 (80 vol \% of $95 \mathrm{RON}$ European gasoline and $20 \mathrm{vol} \%$ of $56 \mathrm{CN}$ European diesel fuel) and $\mathrm{G}^{\prime} \mathrm{D} 15$ (85 vol \% of $91 \mathrm{RON}$ US gasoline and $15 \mathrm{vol} \%$ of $56 \mathrm{CN}$ European diesel fuel). The volatility characteristics of these fuels are shown in Figure 2, where the volume percentage recovered at a given temperature in the ASTM D86 volatility test is plotted against the temperature. The fuel properties are listed in Table 2. The diesel fuel is a commercial low-sulphur European diesel fuel with a $\mathrm{CN}$ of 56 with a boiling-point range between $162^{\circ} \mathrm{C}$ and $365^{\circ} \mathrm{C}$ while the boiling-point range of the gasoline fuel is between $46^{\circ} \mathrm{C}$ and $195^{\circ} \mathrm{C}$. Unfortunately, the RON and the motor octane number (MON) cannot be measured in the Cooperative Fuel Research $\left(\mathrm{CFR}^{\mathrm{TM}}\right)$ engine for diesel fuel because of its low volatility and the CNs of the gasoline fuels, and the blended fuels are also estimated using equation (6) $(\mathrm{CN}=54.6-0.42 \mathrm{RON})$ from the paper by Kalghatgi. ${ }^{13}$ The fuels had a sufficient amount of lubricity additive (300 ppm of Paradyne R655 from Infineum) to ensure that the lubricity scar size was well within the European specification. It can also be seen from Table 2 that all the fuels have similar gravimetric heats of combustion. The fuel consumption was calculated using the measured exhaust emissions and air consumption rate because there were problems of stability with the fuel flow meter at the low flow rates encountered for the volatile fuels; this is less desirable than direct measurements of the fuel consumption. It is worth noting that, even for GD20, the flash point will be comparable with that of gasoline and it would be

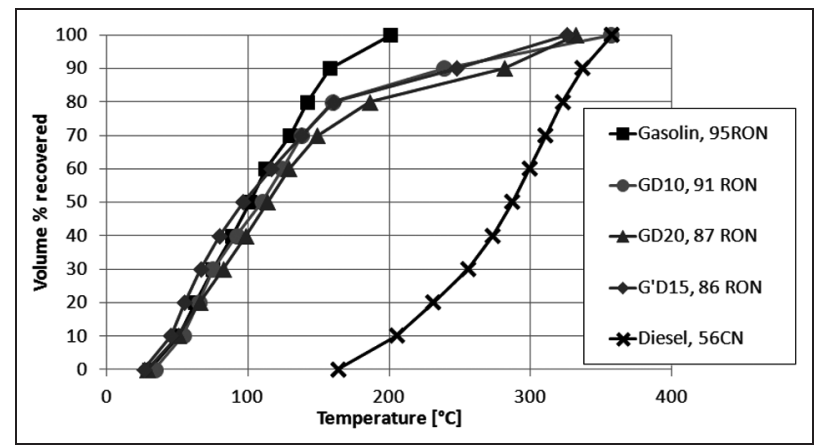

Figure 2. Volatility characteristics of the fuels tested in the ASTM volatility test. RON: research octane number. 
Table 2. Properties of fuels tested.

\begin{tabular}{|c|c|c|c|c|c|c|c|c|c|}
\hline & $\begin{array}{l}\text { Density } \\
\left(\mathrm{g} / \mathrm{cm}^{3}\right)\end{array}$ & $\mathrm{DCN}$ & $\begin{array}{l}\text { Aromatics } \\
\text { (vol\%) }\end{array}$ & $\begin{array}{l}\text { Heat of } \\
\text { combustion } \\
(\mathrm{MJ} / \mathrm{kg})\end{array}$ & $\begin{array}{l}\text { Sulphur } \\
\text { (mg/kg) }\end{array}$ & $\begin{array}{l}\text { Lubricity } \\
(\mu \mathrm{m})\end{array}$ & RON & MON & $\begin{array}{l}\text { Hydrogen- } \\
\text { to-carbon ratio }\end{array}$ \\
\hline Diesel (56 CN) & 0.833 & 56.2 & 25.2 & 42.9 & 7 & 285 & - & - & 1.97 \\
\hline Gasoline (95 RON) & 0.742 & $\approx 15^{\mathrm{a}}$ & 33.45 & 43.3 & $<10$ & 254 & 96.2 & 84.9 & 1.8 \\
\hline GDIO & 0.753 & $\approx 17^{\mathrm{a}}$ & 33 & 43.2 & $<10$ & 255 & 91.4 & 81.5 & 1.81 \\
\hline GD20 & 0.7644 & $\approx 18^{\mathrm{a}}$ & 31 & 43.1 & $<10$ & 250 & 87.2 & 77.5 & 1.82 \\
\hline G'DI5 & 0.7519 & $\approx 19^{a}$ & 31 & 43.1 & $<10$ & 249 & 85.6 & 77.7 & 1.82 \\
\hline
\end{tabular}

DCN: derived cetane number; RON: research octane number; MON: motor octane number; CN: cetane number.

${ }^{a}$ The DCNs of gasoline and GDIO are estimated using equation (6) $(\mathrm{CN}=54.6-0.42 \mathrm{RON})$ from the paper by Kalghatgi. ${ }^{13}$

safe to carry the fuel in a fuel tank in a car; the vapour mixture above the liquid will be too rich for combustion. However, this might not be the case for higher percentages of diesel fuel in the blend.

\section{Results and discussion}

In the discussion below, all the values for the crank angle (CA) (in degrees) are expressed in relation to the top dead centre (TDC) of the compression stroke, which is zero; the TDC on the exhaust stroke is $360^{\circ} \mathrm{CA}$. The pressure signals are averaged over 250 cycles, and the HRRs are calculated from the pressure signals and averaged over 250 cycles. Combustion phasing parameters such as the crank angle at which $50 \%$ of total heat release has taken place (CA50) are calculated from the integrated average heat release.

\section{No EGR and start-of-injection sweep}

We shall first consider the low-load case at $1200 \mathrm{r} / \mathrm{min}$. For each fuel and nozzle, the fuelling rate was fixed to obtain an IMEP at a CA50 of $10^{\circ} \mathrm{CA}$. The start of injection (SOI) is the CA position of the electric signal that marks when the injection starts rather than when the actual fuel flow starts, which might be measured with a needle lift device. Over the SOI range considered, the IMEP varies little for the high-CN fuels and by up to $10 \%$ for the low-CN fuels. The emission results are shown as indicated specific values to account for these changes in the IMEP.

Engine speed, 1200 r/min; IMEP, 4 bar; no EGR; inlet pressure, I.I bar; injection pressure, 250 bar. The fuelling rate was fixed to obtain an IMEP of around 4 bar at a CA50 of $10^{\circ} \mathrm{CA}$ for each fuel. Two nozzles are investigated with an injection pressure of 250 bar for gasoline-type fuels and the results are compared with those for diesel fuel by using nozzle 01 with an injection pressure of 650 bar, which is the recommended pressure for diesel fuel in this engine in these operating conditions. The normalised global $\lambda$ value is around 2.6 and the smoke levels were low, with a filter smoke number (FSN) of less than 0.08 for D1 (conventional diesel), which had the highest level compared with others in these conditions. Figure 3 shows CA50 versus the SOI. The combustion delay (CD), which is given by $\mathrm{CD}=\mathrm{CA} 50$ - SOI, is a reasonably good parameter to help us to understand the fuel effects in this type of PPCI combustion. The fuels GD20 and G'D15 have similar CDs while GD10 shows the longest ignition delay, and also the longest $C D$, which can be inferred from Figure 3 . The longer the value of $\mathrm{CD}$, the more premixed the fuel and air are at the time of the main combustion. For all fuels, combustion starts after the injection is complete in these low-load conditions, but the mixture strengths of the mixture packets where combustion takes place differ because of different ignition delays. When the CD is long, as for fuel GD10, combustion occurs when the fuel and air are better mixed. The overall mixture strength, in mixture packets which burn, will be nearer the global mixture strength which is very lean $(\lambda=$ 2.6). In contrast, diesel fuel ignites very soon after injection starts and the mixture packets that burn will be comparatively richer. Autoignition will take place in rich mixture packets and produce HRRs and a higher combustion temperature. This results in high $\mathrm{NO}_{x}$ emissions in Figure 4. The ignition delays, for highRON fuels can be reduced by reducing the injection pressure in these operating conditions. ${ }^{5,14}$ Presumably

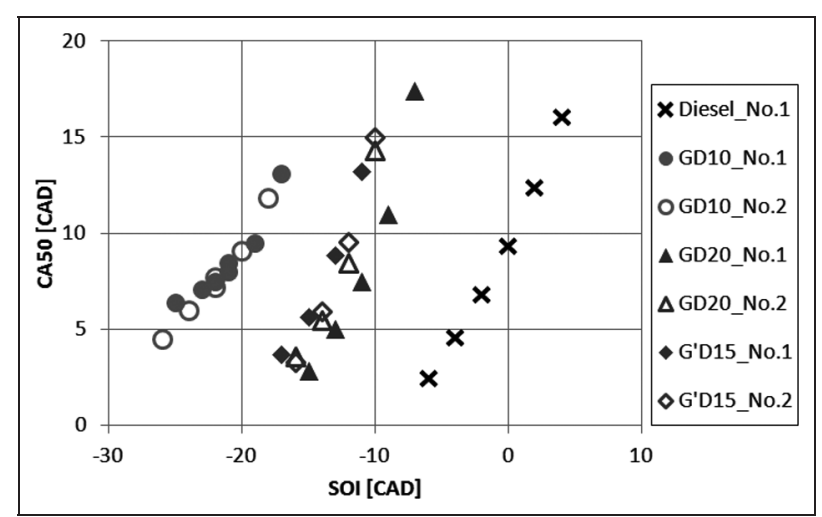

Figure 3. CA50 versus $\mathrm{SOI}$ at an engine speed of $1200 \mathrm{r} / \mathrm{min}$, an IMEP of $4 \mathrm{bar}$, an injection pressure of $250 \mathrm{bar}$ ( $650 \mathrm{bar}$ for diesel), no EGR and an inlet air temperature of $60^{\circ} \mathrm{C}$.

CA50: crank angle at which $50 \%$ of total heat release has taken place; CAD: degrees crank angle; SOI: start of injection. 


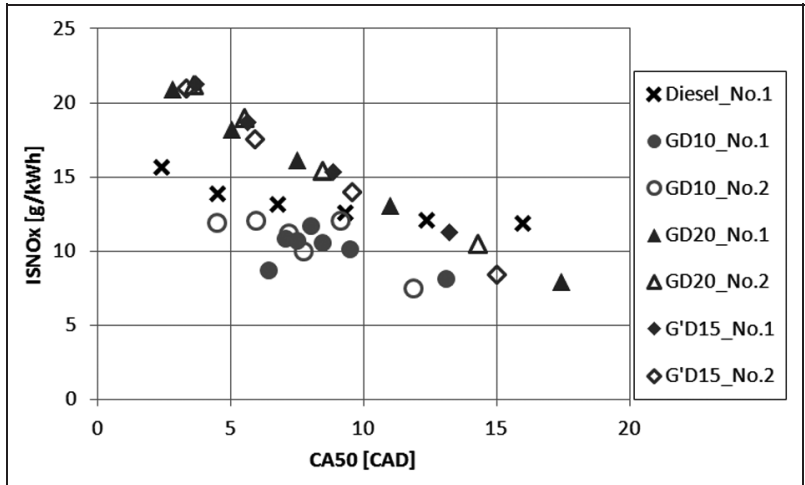

Figure 4. $I \mathrm{SNO}_{x}$ versus $\mathrm{CA} 50$ at an engine speed of $\mid 200 \mathrm{r} /$ min, an IMEP of 4 bar, an injection pressure of 250 bar $(650 \mathrm{bar}$ for diesel), no EGR and an inlet air temperature of $60^{\circ} \mathrm{C}$. $\mathrm{ISNO}_{x}$ : indicated specific nitrogen oxides; CA50: crank angle at which $50 \%$ of total heat release has taken place; CAD: degrees crank angle.



Figure 5. MPRR versus $C A 50$ at an engine speed of $1200 \mathrm{r} / \mathrm{min}$, an IMEP of 4 bar, an injection pressure of 250 bar (650 bar for diesel), no EGR and an inlet air temperature of $60^{\circ} \mathrm{C}$.

MPRR: maximum pressure rise rate; CA50: crank angle at which $50 \%$ of total heat release has taken place; CAD: degrees crank angle.

this is because of less vigorous mixing, which leads to generally richer mixture packets that ignite earlier. With the CD slightly longer, as for GD20 and G'D15, combustion will start with the mixture packets still rich but nearer the stoichiometric mixture strength, on average, compared with the diesel fuel. Hence these fuels will give more $\mathrm{NO}_{x}$ emissions than diesel will. With longer CDs and more mixing of fuel and air, as for GD10, heat release will occur in mixture packets that will be much nearer the global mixture strength, which is very lean. This results in lower $\mathrm{NO}_{x}$ levels (see the paper by Kalghatgi et al. ${ }^{5}$ for more discussion of this point). For the same reason, the MPRR is lower for GD10 in Figure 5. However, the MPRR for high-RON fuels is increased by reducing the injection pressure in these operating conditions. This is because of the reduction in the ignition delays and less vigorous mixing. As noted in a previous study, ${ }^{14}$ the faster and higher initial heat release for diesel fuel has a higher MPRR than for high-RON fuels for CA50 $>5^{\circ} \mathrm{CA}$.

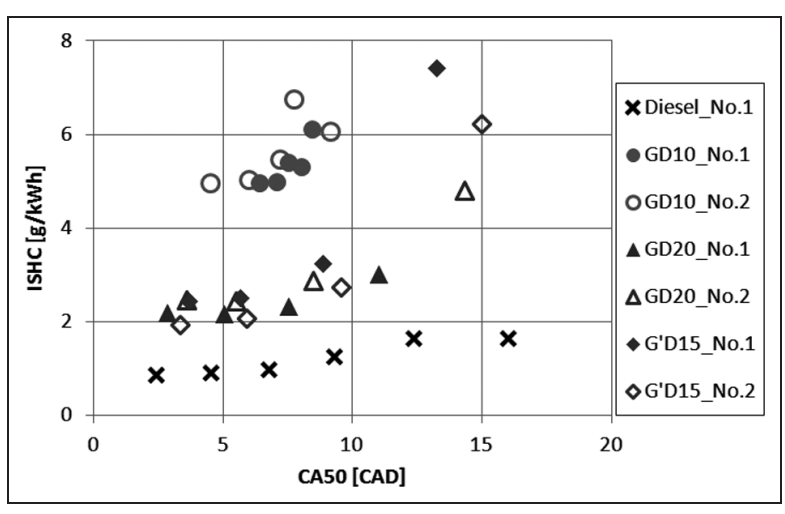

Figure 6. ISHC versus CA50 at an engine speed of $1200 \mathrm{r} / \mathrm{min}$, an IMEP of 4 bar, an injection pressure of 250 bar $(650 \mathrm{bar}$ for diesel), no EGR and an inlet air temperature of $60^{\circ} \mathrm{C}$. ISHC: indicated specific hydrocarbons; CA50: crank angle at which 50\% of total heat release has taken place; CAD: degrees crank angle.

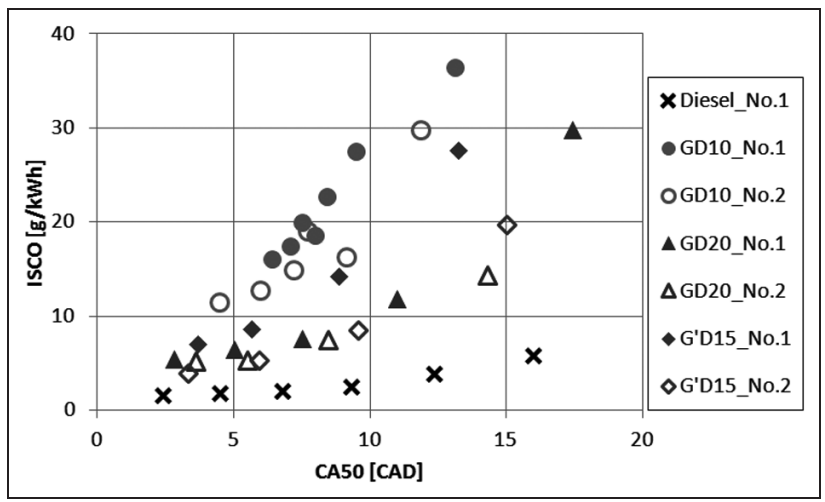

Figure 7. ISCO versus CA50 at an engine speed of $1200 \mathrm{r} / \mathrm{min}$, an IMEP of 4 bar, an injection pressure of 250 bar ( 650 bar for diesel), no EGR and an inlet air temperature of $60^{\circ} \mathrm{C}$.

ISCO: indicated specific carbon monoxide; CA50: crank angle at which $50 \%$ of total heat release has taken place; CAD: degrees crank angle.

In fact, at low loads in passenger car CI engines, this is a problem because it increases noise. It is common to have a pilot injection before TDC to produce heat before the main injection in order to push the main combustion towards a mixing-controlled mode and to reduce the peak HRR. This reduces the efficiency and increases the smoke emissions, which can be avoided using a gasoline-like fuel. As noted before, ${ }^{4}$ when the overall mixture is very lean, more premixed combustion leads to higher $\mathrm{HC}$ and $\mathrm{CO}$ emissions. The high-RON fuels show higher $\mathrm{HC}$ and $\mathrm{CO}$ emissions than diesel fuel does in Figures 6 and 7, even with the lower injection pressure. However, the $\mathrm{HC}$ and $\mathrm{CO}$ emissions for

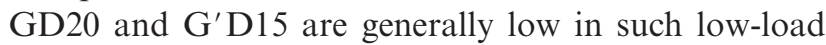
conditions. A lower injection pressure should help to reduce the $\mathrm{HC}$ and $\mathrm{CO}$ emissions with decreasing ignition delay and they are close to the levels obtained for diesel fuel by conventional injection timing.

Over the SOI range considered in part-load and lowspeed conditions, the high-RON fuels have higher $\mathrm{HC}$ 
and $\mathrm{CO}$ emissions than diesel fuel does, but these problems were significantly alleviated by managing the mixing by reducing the injection pressure and increasing the intake air temperature so that combustion avoided over-mixing for stable operation. ${ }^{5}$ Hence we have used a much lower pressure for the high-RON fuels than for the diesel fuel: 250 bar versus 650 bar.

Engine speed, 1200 r/min; IMEP, 2 bar; no EGR; inlet pressure, I.I bar; injection pressure, 250 bar. Smoke and indicated specific nitrogen oxide $\left(\mathrm{ISNO}_{x}\right)$ levels for all fuels, including fuel D1 (conventional diesel), are relatively low and thus only indicated specific hydrocarbon (ISHC) and indicated specific carbon monoxide (ISCO) emissions are shown in these test conditions. Figures 8 and 9 show the $\mathrm{HC}$ and $\mathrm{CO}$ emission results respectively with different fuels, nozzles and intake temperatures with the CA50 fixed at $10^{\circ} \mathrm{CA}$; the SOIs of each

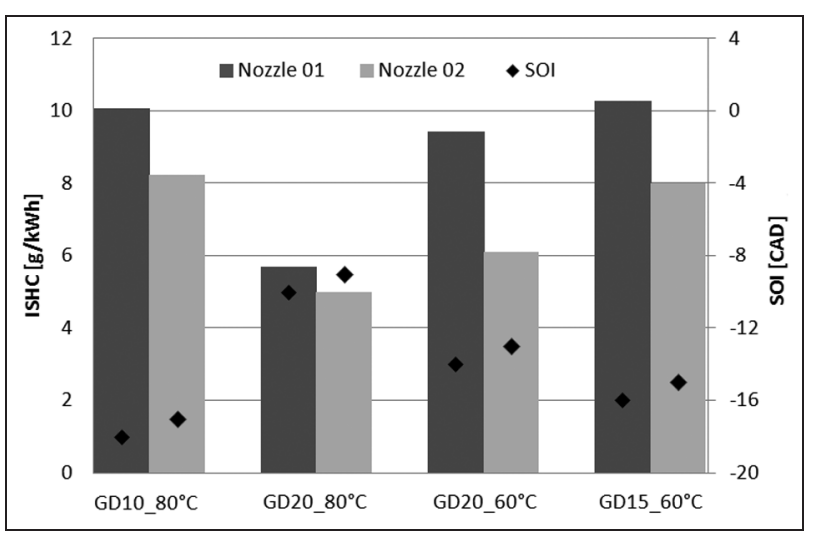

Figure 8. ISHC at an engine speed of $1200 \mathrm{r} / \mathrm{min}$, an IMEP of 2 bar, an injection pressure of 250 bar, no EGR and inlet air temperatures of $60^{\circ} \mathrm{C}$ and $80^{\circ} \mathrm{C}$ and where CA50 is fixed at $10^{\circ} \mathrm{CA}$.

ISHC: indicated specific hydrocarbons; SOI: start of injection; CAD: degrees crank angle.

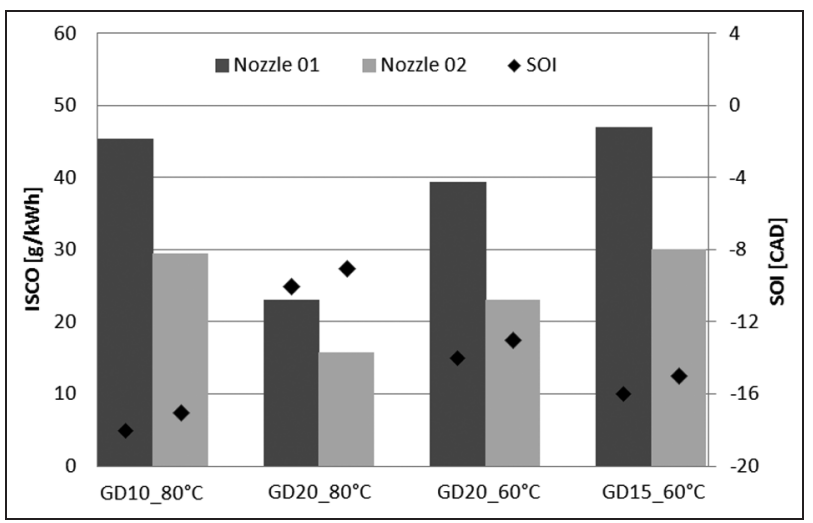

Figure 9. ISCO at an engine speed of $1200 \mathrm{r} / \mathrm{min}$, an IMEP of 2 bar, an injection pressure of 250 bar, no EGR and inlet air temperatures of $60^{\circ} \mathrm{C}$ and $80^{\circ} \mathrm{C}$ and where CA50 is fixed at $10^{\circ} \mathrm{CA}$.

ISCO: indicated specific carbon monoxide; SOI: start of injection; CAD: degrees crank angle. fuel and nozzle are shown also on a secondary axis. First, GD10 and GD20 are compared at a high temperature $\left(80^{\circ} \mathrm{C}\right)$ in the intake manifold and GD10 shows higher $\mathrm{HC}$ and $\mathrm{CO}$ emissions with longer ignition delays (injection timing around $8^{\circ}$ earlier). In the cases of lower intake air temperatures, G'D15 and GD20 also show high $\mathrm{HC}$ and $\mathrm{CO}$ emissions with nozzle 01 at $60^{\circ} \mathrm{C}$. A high temperature in the intake manifold helps to reduce $\mathrm{HC}$ and $\mathrm{CO}$ emissions for highRON fuels in low-load conditions. In these conditions, the normalised global air-to-fuel ratio $\lambda$ is over 4.0 and the local mixture strength, in mixture packets which burn, will be nearer the global mixture strength with a long ignition delay for a high-RON fuel such as GD10. Therefore the $\mathrm{HC}$ and $\mathrm{CO}$ emissions are relatively high because of very lean mixtures. In contrast, it seems that nozzle 02 , with a nominally higher orifice diameter, has richer mixture packets that burn compared with nozzle 01 and the ignition delay is also shorter (injection timing around $1^{\circ}$ later). Therefore, the nozzle with a higher flow rate has lower $\mathrm{HC}$ and $\mathrm{CO}$ emissions for all fuels. Additionally, multiple injections should help to reduce $\mathrm{HC}$ and $\mathrm{CO}$ emissions with decreasing ignition delay between the start of the main injection and combustion.

In summary, the fuels (GD20 and $\left.\mathrm{G}^{\prime} \mathrm{D} 15\right)$ can ignite much more easily by managing the mixing through a high intake air temperature and injection strategies, even if the engine was run in very-low-load conditions approaching an idling condition.

\section{EGR sweep}

The engine can be run on high-octane-number fuels to give very low $\mathrm{NO}_{x}$ levels (less than $0.5 \mathrm{~g} / \mathrm{kWh}$ ) and smoke levels (FSN less than 0.1), e.g. at IMEPs of 4 bar and 10 bar at an engine speed of $2000 \mathrm{r} / \mathrm{min}$ in contrast with the diesel fuel with high $\mathrm{CN} .^{4,14}$ The results for all fuels will be summarised again later in this paper. In this section we consider the effect of EGR on each of the fuels and nozzles at $3000 \mathrm{r} / \mathrm{min}$ and $4000 \mathrm{r} / \mathrm{min}$, with an IMEP of 10 bar. As the engine speed increases, the time available for combustion decreases. Hence, if the ignition delay is too long, ignition cannot happen before the pressure and temperature in the cylinder are reduced rapidly during the expansion stroke and combustion fails. In such cases, combustion can be ensured by increasing the intake pressure slightly. ${ }^{4}$ In the present case, CA50 is fixed at $11^{\circ} \mathrm{CA}$ after top dead centre (ATDC) and the intake pressure, at 2.0 bar absolute, is higher than in low-load conditions. Generally a higher injection pressure is used to compensate for the higher engine speed by not increasing the injection duration in CA terms. However, the previous tests ${ }^{14}$ suggest that larger injector hole diameters and lower injection pressures are better for gasoline-type fuels in PPCI. The fuelling rate is chosen to obtain a nominal IMEP without EGR, and EGR is then varied with the fuelling rate fixed. The EGR rate is defined as the intake $\mathrm{CO}_{2}$ concentration expressed as a percentage of the exhaust 
$\mathrm{CO}_{2}$ concentration. As EGR increases, both the oxygen concentration in the intake and the normalised air-tofuel ratio $\lambda$ decrease.

Engine speed, $3000 \mathrm{r} / \mathrm{min}$; IMEP, 10 bar; CA50, $11^{\circ} \mathrm{CA}$; inlet pressure, 2.0 bar; injection pressures, 400 bar (I I00 bar for diesel fuel). First, high-RON fuels are investigated with an injection pressure of 400 bar using the two nozzles and they are compared with diesel fuel by using nozzle 01 (the standard nozzle), with an injection pressure of 1100 bar (the recommended pressure). Qualitatively, at higher engine speeds, less time is available for autoignition and a higher intake pressure will make autoignition easier. A useful time constant in this type of combustion is the ignition dwell (IDW), the difference between the end of the injection (EOI) and the crank angle at which $10 \%$ of total heat release has taken place (CA10), i.e. IDW $=$ CA10 - EOI. If the IDW is negative or near zero, combustion will be the classical diesel combustion in a lifted diffusion flame. Even if it is positive but small, the part of the fuel entering the cylinder at the EOI will have had little chance to mix with air before burning. In both cases, at least a part of the fuel will burn at a mixture strength rich enough to produce soot. In Figures 10 and 11, the IDW and smoke levels respectively are plotted against EGR first for these fuels in these operating conditions. At low EGR levels, only IDWs for gasoline fuel are high and others are near zero. For gasoline, with an RON of 95, smoke levels are very low at all EGR levels but the maximum EGR possible is around $30 \%$ because combustion became unstable at higher levels. With high injection pressures, the smoke levels for diesel fuel are low in low-EGR conditions. However, if smoke is formed in the first place as with diesel fuel, engine-out smoke emissions are increased as EGR is increased because of the reduction in smoke oxidation caused by the decreasing oxygen

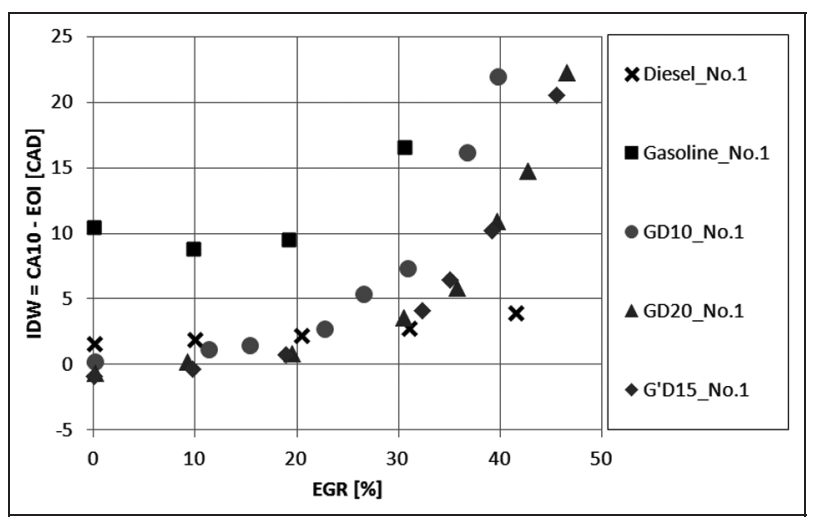

Figure 10. IDW time versus EGR at an engine speed of $3000 \mathrm{r} / \mathrm{min}$, an IMEP of $10 \mathrm{bar}$, an injection pressure of $400 \mathrm{bar}$ (with an injection pressure of I 100 bar for diesel), an inlet air temperature of $60^{\circ} \mathrm{C}$ and where CA50 is fixed at $11^{\circ} \mathrm{CA}$. IDW: injection dwell; CA I0: crank angle at which $10 \%$ of total heat release has taken place; EOI: end of injection; CAD: degrees crank angle; EGR, exhaust gas recirculation.

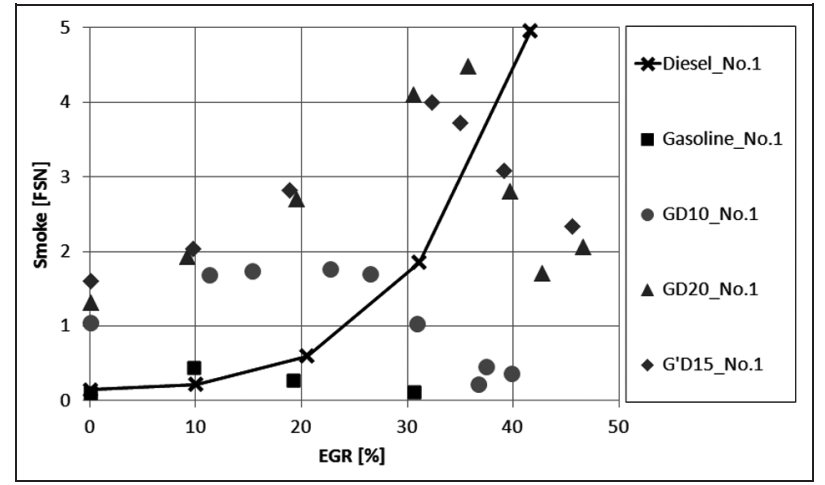

Figure I I. Smoke versus EGR at an engine speed of $3000 \mathrm{r} /$ min, an IMEP of 10 bar, an injection pressure of 400 bar (with an injection pressure of I 100 bar for diesel), an inlet air temperature of $60^{\circ} \mathrm{C}$ and where CA50 is fixed at $11^{\circ} \mathrm{CA}$. FSN: filter smoke number; EGR, exhaust gas recirculation.

level and decreasing combustion temperature, even if ignition delays are slightly increased. At an injection pressure of 400 bar, GD10, GD20 and G'D15 have short delay times in low EGR conditions and high smoke emissions but the IDWs are increased by increasing EGR. In particular, the IDW increases strongly for GD10 in high-EGR conditions and is sufficiently high that even the fuel injected later has a chance to mix well with air and there is very little smoke. The smoke levels for GD20 and G'D15 are slightly decreased by increasing EGR but there are still high smoke emissions. The smoke emissions depend on the time history of the mixture strength and the burned gas temperature in all the mixture, which in turn is determined by the mixing of fuel and air. The processes involved are complex and depend on the ignition delay, the dilution of oxygen and the surrounding temperature and flow field, among other things. It seems that, for GD20 and G'D15, a high injection pressure or swirl is required to reach low smoke levels in these conditions. The IDW and smoke level are plotted against EGR for $\mathrm{G}^{\prime}$ D15 with different nozzles and injection pressures and they are compared with the corresponding values for diesel fuel in these operating conditions (Figures 12 and 13 respectively). The IDWs increase with increasing flow rate and injection pressure until around 40\% EGR and are similar at very high EGR levels. Of the smoke emissions compared, smoke is slightly reduced by using nozzle 02 which has a large orifice size. Very low smoke emissions are obtained by increasing the injection pressure at all EGR levels. In high-EGR conditions, the smoke levels for $G^{\prime} D 15$ are lower than for diesel fuel. However, the MPRRs for the high-RON fuels are higher than for diesel fuel in Figure 14 because combustion is taking place in a relatively rich premixed phase. The MPRRs for diesel fuel are similar at all EGR levels while the smoke emissions are variable. For high-RON fuels, a trade-off is observed between the MPRRs and the smoke emissions. For both GD20 (87 RON) and G'D15 (86 RON) the MPRRs are generally lower but smoke emissions 


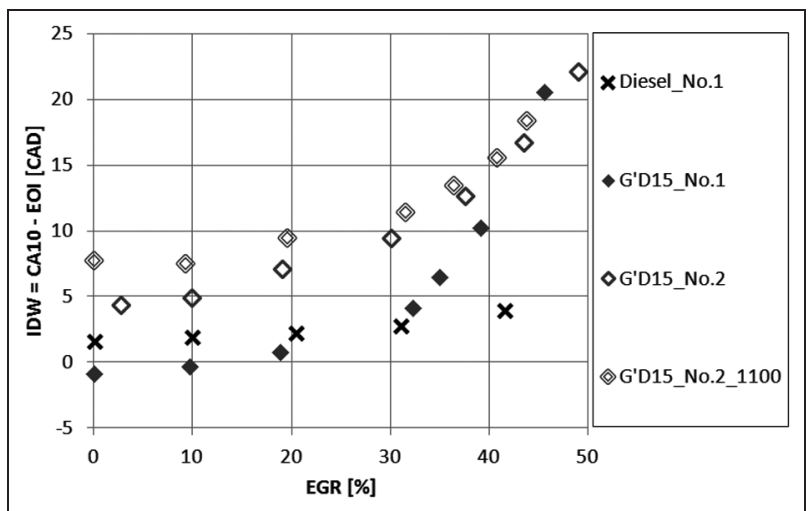

Figure I2. IDW time versus EGR at an engine speed of $3000 \mathrm{r} /$ min, an IMEP of 10 bar, injection pressures of 400 bar and I I 00 bar (with an injection pressure of I 100 bar for diesel), an inlet air temperature of $60^{\circ} \mathrm{C}$ and where $\mathrm{CA} 50$ is fixed at $11^{\circ} \mathrm{CA}$. IDW: injection dwell; CA I0: crank angle at which I0\% of total heat release has taken place; EOI: end of injection; CAD: degrees crank angle; EGR, exhaust gas recirculation.

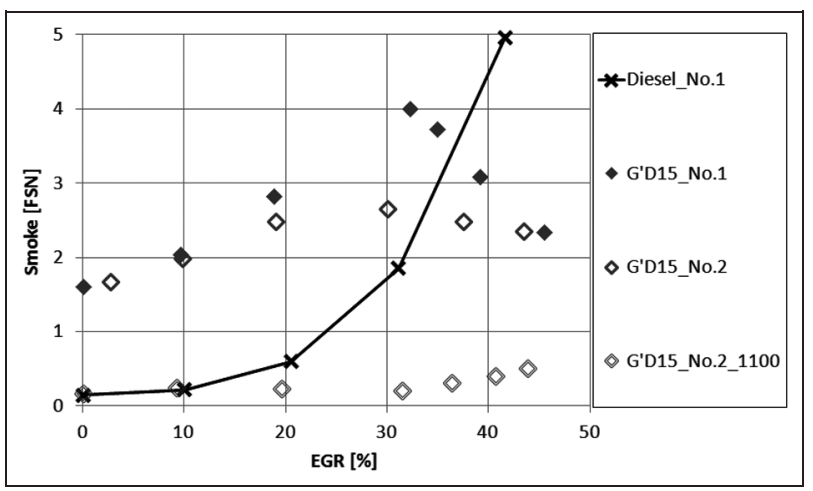

Figure 13. Smoke versus EGR at an engine speed of $3000 \mathrm{r} / \mathrm{min}$, an IMEP of 10 bar, injection pressures of 400 bar and I 100 bar (with an injection pressure of I I00 bar for diesel), an inlet air temperature of $60^{\circ} \mathrm{C}$ and where CA50 is fixed at $11^{\circ} \mathrm{CA}$. FSN: filter smoke number; EGR, exhaust gas recirculation.



Figure I4. Smoke versus MPRR at an engine speed of $3000 \mathrm{r} / \mathrm{min}$, an IMEP of 10 bar, injection pressures of 400 bar and I 100 bar (with an injection pressure of I 100 bar for diesel), an inlet air temperature of $60^{\circ} \mathrm{C}$ and where CA50 is fixed at $11^{\circ} \mathrm{CA}$. FSN: filter smoke number; MPRR: maximum pressure rise rate; CAD: degrees crank angle. are higher than for GD10 (91 RON) and gasoline (95 RON). With GD10 and gasoline, combustion occurs after fuel injection is completed so that the probability of smoke formation is significantly reduced, even at high loads. When high levels of EGR are used to control $\mathrm{NO}_{x}$, it does not matter that the oxygen level in the cylinder is reduced since not much smoke is formed in the first place and engine-out smoke can remain very low. However, high peak HRRs that lead to high peak pressure rise rates are a consequence of the premixed combustion mode at high loads, and similar trends are also observed for $\mathrm{G}^{\prime} \mathrm{D} 15$ at high injection pressures. This can be alleviated by using multiple injections. ${ }^{4}$

Figure 15 shows that the fuel consumptions for highRON fuels are slightly higher than for diesel fuel at low EGR levels, presumably because diesel fuel is run with a high injection pressure, and higher-pressure injection produces faster sprays, increasing the spray penetration and reducing the droplet size. However, the high-RON fuels have lower indicated specific fuel consumptions (ISFCs) than diesel fuel does at very high EGR levels. The delay period must also be controlled to hold the maximum cylinder gas pressure for improving the efficiency, and the heat release is not spread out too far away from TDC. When combustion phasing is fixed, as in the present case, as EGR is increased for a given fuel, the combustion temperatures and consequently the heat losses decrease and the fuel consumption decreases. ${ }^{10}$ Figure 16 shows smoke versus ISNO $_{x}$ by using two nozzles (solid lines) and two injection pressures (dashed lines) and the results are selected at the lowest $\mathrm{NO}_{x}$ level possible in these conditions with EGR sweeps; our targets are also shown in the black box. Diesel fuel with nozzle 01 and an injection pressure of 1100 bar can be run in these conditions with sufficient EGR to obtain an $\mathrm{ISNO}_{x}$ value below $0.5 \mathrm{~g} / \mathrm{kWh}$ but the smoke emissions are increased dramatically at high EGR. The results for diesel fuel are the nearest value to the target

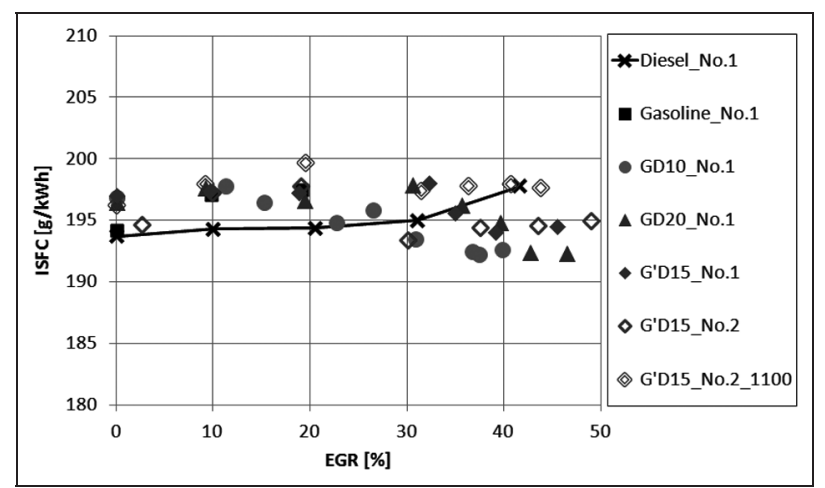

Figure I5. ISFC versus EGR at an engine speed of $3000 \mathrm{r} / \mathrm{min}$, an IMEP of 10 bar, injection pressures of 400 bar and II 00 bar (with an injection pressure of I 100 bar for diesel), an inlet air temperature of $60^{\circ} \mathrm{C}$ and where CA50 is fixed at $11^{\circ} \mathrm{CA}$. ISFC: indicated specific fuel consumption; EGR, exhaust gas recirculation. 


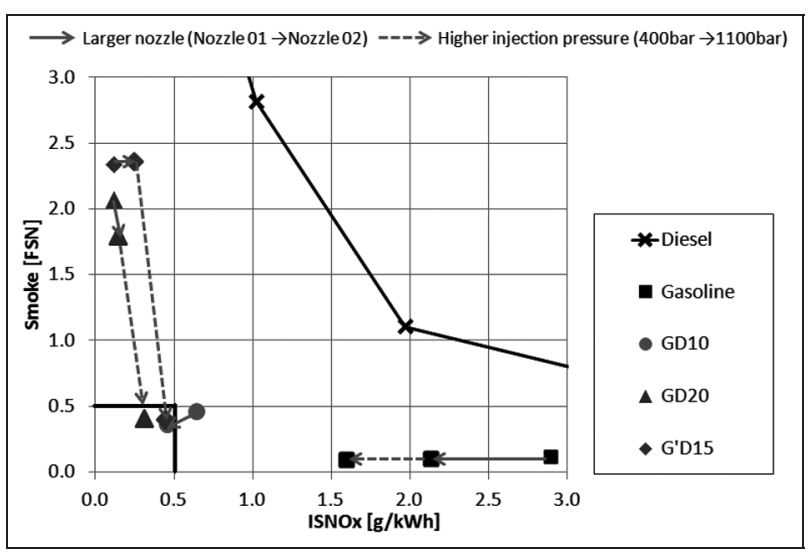

Figure 16. Smoke versus ISNO $x$ at an engine speed of $3000 \mathrm{r} / \mathrm{min}$, an IMEP of 10 bar, injection pressures of 400 bar and I I 00 bar (with an injection pressure of I 100 bar and nozzle 01 for diesel), an inlet air temperature of $60^{\circ} \mathrm{C}$ and where CA50 is fixed at $11^{\circ} \mathrm{CA}$.

FSN; filter smoke number; ISNO;: indicated specific nitrogen oxides.

with respect to the trade-off between smoke and $\mathrm{NO}_{x}$ levels. Even if the engine is operated with a high injection pressure, diesel fuel has high smoke emissions and $\mathrm{ISNO}_{x}$ emissions in these conditions. In the case of gasoline, the smoke emissions are very low but the maximum EGR is limited because of unstable combustion. The lowest $\mathrm{ISNO}_{x}$ level is around $1.6 \mathrm{~g} / \mathrm{kWh}$ by using nozzle 02 with an injection pressure of $1100 \mathrm{bar}$. The trade-offs for GD10 fuel are very close to the target even with a low injection pressure and nozzle 01; by using nozzle 02, GD10 fuel can obtain lower smoke and $\mathrm{NO}_{x}$ levels than the levels of our targets. The other high-RON fuels, GD20 and G'D15, can also be run with sufficient EGR to obtain $\mathrm{ISNO}_{x}$ levels below $0.5 \mathrm{~g} / \mathrm{kW} \mathrm{h}$ but the smoke emissions are higher than the target levels with a low injection pressure. GD20 and $\mathrm{G}^{\prime} \mathrm{D} 15$ can attain less than the target levels only with a high injection pressure in these conditions. Note that the injection pressure used for high-RON fuels is only 400 bar; the smoke levels for diesel fuel would be very much higher at such a low injection pressure than shown here.

Engine speed, $4000 \mathrm{r} / \mathrm{min}$; IMEP, $10 \mathrm{bar}$; CA50, $11^{\circ} \mathrm{CA}$; inlet pressure, $2.0 \mathrm{bar}$; injection pressures, $400 \mathrm{bar}$ (I $100 \mathrm{bar}$ for diesel fuel). The engine operating conditions are identical with those considered in the previous section except that the engine speed is faster. The results for the CD, MPRR and ISFC show similar trends to the results in the previous section and thus only the smoke and $\mathrm{ISNO}_{x}$ levels are discussed for this condition. Figure 17 shows the smoke emissions against $\mathrm{ISNO}_{x}$ level at an engine speed of $4000 \mathrm{r} / \mathrm{min}$ and the results are again the nearest values to the target in the trade-offs between smoke and $\mathrm{NO}_{x}$ for each fuel (the same as in Figure 16) that could be achieved. Diesel fuel with nozzle 01 and an injection pressure of 1100 bar again has a high smoke level at high EGR levels in these conditions.

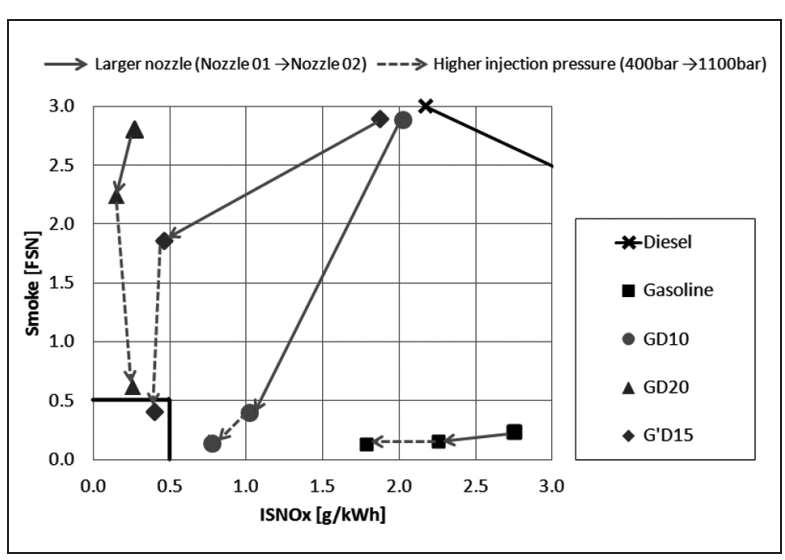

Figure 17. Smoke versus ISNO $x$ at an engine speed of $4000 \mathrm{r} / \mathrm{min}$, an IMEP of 10 bar, injection pressures of $400 \mathrm{bar}$ and 1100 bar (with an injection pressure of I I 00 bar and nozzle 01 for diesel), an inlet air temperature of $60^{\circ} \mathrm{C}$ and where CA50 is fixed at $11^{\circ} \mathrm{CA}$.

FSN; filter smoke number; ISNO $\mathrm{N}_{x}$ indicated specific nitrogen oxides.

Increasing EGR leads to lower $\mathrm{NO}_{x}$ and higher smoke emissions for diesel fuel. In the case of gasoline, smoke emissions are very low but the maximum EGR is also limited in these conditions. The lowest $\mathrm{ISNO}_{x}$ level is around $1.8 \mathrm{~g} / \mathrm{kWh}$ by using nozzle 02 with an injection pressure of 1100 bar. The trade-offs for GD10 fuel are a slightly higher $\mathrm{ISNO}_{x}$ level than the target value but very close to the target value with an even lower injection pressure. The maximum EGR for GD10 is around $35 \%$ in these conditions because, for higher EGR, combustion became unstable and the lowest $\mathrm{ISNO}_{x}$ emission level is around $0.7 \mathrm{~g} / \mathrm{kWh}$ in these conditions. Combustion stability can be regained by increasing the intake pressure. ${ }^{4}$ GD20 and $\mathrm{G}^{\prime} \mathrm{D} 15$ can also be run with sufficient EGR to obtain an $\mathrm{ISNO}_{x}$ value below the target, and smoke emissions for the fuels are also near the target with a high injection pressure in these conditions. Increasing the injector hole size would enable the injection event to be completed more quickly for a fixed injection pressure and the amount of fuel injected. With increasing EGR, smoke emissions increase with fuels in the diesel autoignition range $(\mathrm{CN}$ $>40$ ) because of the very short ignition delays and dilution of oxygen. With high-RON fuels, good mixing is facilitated by the fact that there is much more time available for mixing before autoignition.

\section{Trade-offs of emissions}

In this section we consider the low emissions available at each test point (TP). The TPs are described in Table 3. Three TPs in low-load conditions and another three TPs at higher-load conditions are selected for this study. The TPs were defined with their IMEPs and the engine speeds, both of which were maintained constant for all the tests under a TP condition. The SOI and the rail pressure were varied within the shown limits (up to 
Table 3. Conditions for TPs.

\begin{tabular}{|c|c|c|c|c|c|c|}
\hline \multirow[t]{2}{*}{ Parameter (units) } & \multicolumn{6}{|c|}{ Value for the following test points } \\
\hline & TPI & TP2 & TP3 & TP4 & TP5 & TP6 \\
\hline Engine speed ( $\mathrm{r} / \mathrm{min})$ & 1200 & 1200 & 2000 & 2000 & 3000 & 4000 \\
\hline Rail pressure, diesel (bar) & - & 650 & 900 & 900 & 1100 & 1100 \\
\hline Rail pressure, other fuels (bar) & 250 & 250 & 400 & 400 & 400 & 400 \\
\hline IMEP (bar) & 2 & 4 & 4 & 10 & 10 & 10 \\
\hline CA50 (deg CA) & - & - & II & II & II & II \\
\hline Boost pressure (bar) & I.I & 1.1 & 2.0 & 2.0 & 2.0 & 2.0 \\
\hline Exhaust pressure (bar) & I.I & 1.1 & 2.2 & 2.2 & 2.2 & 2.2 \\
\hline Boost temperature $\left({ }^{\circ} \mathrm{C}\right)$ & 80 & 60 & 60 & 60 & 60 & 60 \\
\hline Oil and coolant temperatures $\left({ }^{\circ} \mathrm{C}\right)$ & 90 & 90 & 90 & 90 & 90 & 90 \\
\hline$\lambda($ no EGR) & 4.5 & 2.7 & 4.8 & 2.3 & 2.3 & 2.3 \\
\hline
\end{tabular}

IMEP: indicated mean effective pressure; CA50: crank angle at which 50\% of total heat release has taken place; CA: crank angle; EGR: exhaust gas recirculation.

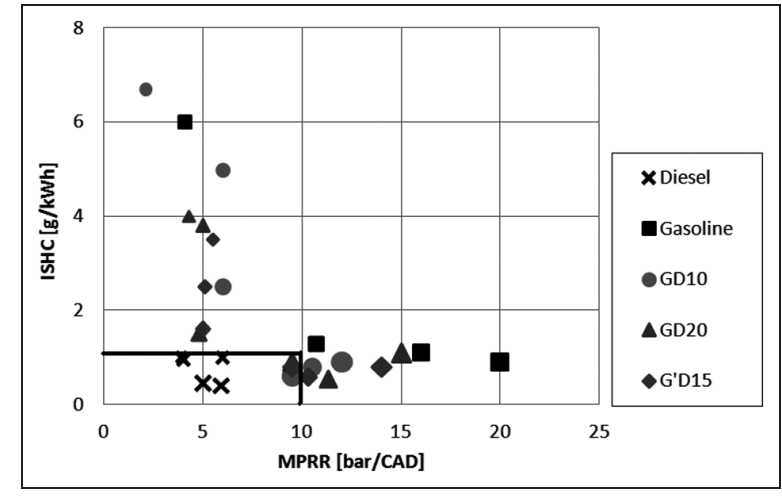

Figure 18. ISHC versus MPRR at six different TPs (Table 3): the sizes of the symbols are increased from TPI (smallest) to TP6 (largest).

ISHC: indicated specific hydrocarbons; MPRR: maximum pressure rise rate; $C A D$ : degrees crank angle.

1100 bar for diesel fuel and up to 400 bar for other fuels). The injection duration was varied to maintain the IMEP as specified in Table 3, while specified levels of $\mathrm{NO}_{x}$ were achieved by varying EGR. Figure 18 shows ISHC against MPRR at six different TPs and the sizes of the symbols are increased from TP1 (smallest) to TP6 (largest). The results are selected at the lowest level possible at each TP with SOI sweeps and EGR sweeps, and our targets are also shown in the black box. Diesel fuel can be run at all conditions to attain ISHC and MPRR values below our target levels but the high-RON fuels in low-load conditions have high $\mathrm{HC}$ emissions, and the MPRRs are also high in highload conditions. This is an inevitable result of lean premixed combustion. If the conditions are such that $\mathrm{NO}_{x}$ and smoke emissions are controlled, the combustion temperatures and the mixture strengths will be such that $\mathrm{HC}$ and $\mathrm{CO}$ do not go to full oxidation even if there is oxygen available. However, GD20 and G'D15 have relatively low $\mathrm{HC}$ and $\mathrm{CO}$ emissions in low-load conditions even if we have not considered any special injection strategies such as multiple injection. Also a

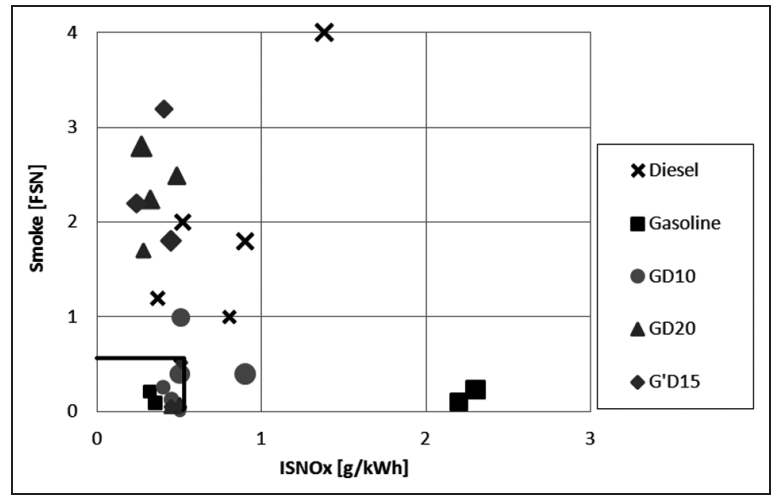

Figure 19. Smoke versus ISNO ${ }_{x}$ at six different TPs (Table 3): the sizes of the symbols are increased from TPI (smallest) to TP6 (largest).

FSN; filter smoke number; ISNO $:$ indicated specific nitrogen oxides.

high peak pressure rise rate can be alleviated by using multiple injections. ${ }^{4}$ Figure 19 shows smoke versus $\mathrm{ISNO}_{x}$ and the black box is again our target for Euro 6 norm for emission. Diesel fuel can be run in most conditions with sufficient EGR to obtain an $\mathrm{ISNO}_{x}$ level below $0.5 \mathrm{~g} / \mathrm{kW}$ h but the smoke emissions are increased dramatically at high EGR. Much higher injection pressures than the 1100 bar used in this work would be needed to reduce the smoke emissions from diesel fuel at such EGR levels. The results for diesel fuel are the nearest value at each TP from the target in the trade-off between smoke and $\mathrm{NO}_{x}$. Gasoline has very low smoke emissions in most conditions but, as noted in the previous section, the EGR level that can be used is limited in higher-load and high-speed conditions. The trade-offs for GD10 fuel are very close to the target in all conditions, and GD10 fuel has lower smoke and $\mathrm{NO}_{x}$ emissions than other fuels do. The high-RON fuel (below 91 RON) can be run in most conditions with suffcient EGR to obtain an ISNO $_{x}$ level below about $0.5 \mathrm{~g} / \mathrm{kW} \mathrm{h}$ with low smoke emissions (an FSN lower than 0.5). However, the emissions are outside the target box at 
$4000 \mathrm{r} / \mathrm{min}$ because of the more difficult ignitions at high engine speeds. This could be solved by utilising a higher intake pressure. Other high-RON fuels, GD20 and $G^{\prime} D 15$, have high smoke emission in high-load conditions with a low injection pressure.

This study shows that $\mathrm{NO}_{x}$ and smoke emissions can be controlled at much higher loads at a given speed with gasoline-like fuels compared with diesel fuels. This would enable downsizing and down-speeding in light-duty engines with associated benefits in fuel economy. ${ }^{15}$ Using multiple injection strategies, ${ }^{16-19}$ low-emission and high-efficiency operation has been achieved at full load in heavy-duty engines using gasoline and ethanol. ${ }^{8,9,20}$

\section{Summary and concluding discussion}

The gasoline and diesel fuels available in the European market and three of their blends are tested in a small (0.537 1) single-cylinder CI engine using two nozzles.

1. The fuels with greater autoignition resistance, namely gasoline and GD10, give high $\mathrm{HC}$ and $\mathrm{CO}$ emissions in low-load conditions and more difficult ignitions at very high EGR. However, low smoke and $\mathrm{NO}_{x}$ emissions are possible by using a largeorifice nozzle even with a low injection pressure.

2. Other fuels, namely GD20 and $\mathrm{G}^{\prime} \mathrm{D} 15$, have relatively low $\mathrm{HC}$ and $\mathrm{CO}$ emission in low-load conditions and can be run with sufficient EGR in a higher-load condition to obtain a low $\mathrm{ISNO}_{x}$ value. However, low smoke emission levels at high EGR are only possible with a high injection pressure in high-load and high-speed conditions.

3. As the engine speed increases, fuels with a greater autoignition resistance have more difficulty igniting at very high EGR. However, smoke and $\mathrm{NO}_{x}$ emissions can be controlled by combination of the RON, the size of the nozzle orifices and the injection pressure at much higher loads at a given speed with gasoline-like fuels compared with diesel fuels.

A high-RON fuel such as GD10 could be run at an engine speed of $4000 \mathrm{r} / \mathrm{min}$ and an IMEP of $10 \mathrm{bar}$ with an injection pressure as low as 400 bar, to obtain low $\mathrm{NO}_{x}$ and smoke levels with acceptable levels of $\mathrm{HC}$ and MPRR. Such low smoke and $\mathrm{NO}_{x}$ levels could not be simultaneously achieved with diesel fuel even with an injection pressure of 1100 bar. The ignition delay can become too long to ensure combustion within the time available with fuels which are resistant to autoignition. This could occur because of over-mixing and over-leaning at low loads when the global equivalence ratio is too high or at high speeds with sufficient EGR to reduce $\mathrm{NO}_{x}$ emissions to acceptable levels. Low injection pressures and larger injector holes help to avoid this by making the mixture more stratified. Of course, with diesel fuel, low injection pressures would cause an increase in smoke emissions by making the mixture even less mixed. The wider volatility range of the gasoline-diesel blends also probably enables more stratification and is beneficial. For instance a fuel in the gasoline boiling-point range with an RON and a MON comparable with those of GD10 (fuel G5 in the paper by Kalghatgi et al. ${ }^{4}$ ) could not be run with an EGR level greater than $37 \%$ in the conditions of TP5. In contrast, GD10 which contains less volatile components from the diesel fuel could be run at higher EGR levels and even in the conditions of TP6 at $4000 \mathrm{r} / \mathrm{min}$. Further work is needed to clarify this point.

There is great scope for reducing the cost of the injection system in high-efficiency CI engines by using very-low-CN fuels. Gasoline-like fuels make premixed CI combustion much easier and yield very significantly lower smoke emissions in low- $\mathrm{NO}_{x}$-level operating conditions than diesel fuel does. The current practical gasoline fuels (with, for example, an RON of 95) become more problematic at low-load and high-speed highEGR operation. Hence the optimum fuels for such systems might have lower octane numbers than current gasoline fuels. The injector variations that we have considered in this work are not large. A narrow-angle direct-injection system will be considered for further study to improve combustions and emissions for highRON fuels by using different injection strategies. Clearly much development work is needed to optimise injectors and injection strategies to make the best use of long ignition delays of gasoline-like fuels to obtain low $\mathrm{NO}_{x}$ and low smoke emissions with a high efficiency from CI engines. Work would also be needed to ensure cold starts; a high-power glow plug or even spark ignition might be needed. Operation at very low loads might be helped by retaining hot internal EGR. Low-NO $\mathrm{NO}_{x}$, low-smoke and high-efficiency CI combustion is likely to benefit from very-low-CN diesel or lowoctane-number gasoline by today's standards and lower injection pressures compared with current CI engines. Moreover, the focuses for after-treatment shifts from $\mathrm{NO}_{x}$ control to $\mathrm{HC}$ and $\mathrm{CO}$ control, probably further simplifying the engine. In passenger car CI engines, there might be a scope for downsizing and/or downspeeding because smoke and $\mathrm{NO}_{x}$ emisssions can be controlled at much higher loads at a given speed. Also, there might be scope for improving the efficiency at light loads by avoiding the correction strategies such as pilot injection to reduce noise. Thus the engine could be cheaper than the advanced diesel engine while retaining or improving its efficiency and the fuel might be easier to make. There is much incentive and also scope to develop such engine combustion systems.

\section{Funding}

This work was supported by the EU contract, Marie Curie Programme (project name: Low Carbon Future Fuels; project grant no. FP7; contract no. 251492). 


\section{Acknowledgements}

The collaboration with RWTH Aachen University was made possible by the above-cited contract. Our colleagues in Shell Technology Centre Thornton, most notably Huw Jones and Bob Head, made the engine experiments possible.

\section{References}

1. Dec JE. A conceptual model of DI diesel combustion based on laser sheet imaging. SAE paper 970873, 1997.

2. Heywood JB. Internal combustion engine fundamentals. New York: McGraw-Hill, 1988, ch 11.

3. Zhao F, Harrington DL and Lai M. Automotive gasoline direct injection engines. Warrendale, PA: SAE International, 2002.

4. Kalghatgi G, Hildingsson L, Harrison AJ and Johansson B. Low $\mathrm{NO}_{x}$ and low smoke operation of a diesel engine using premixed enough compression ignition: effects of fuel auto-ignition quality and volatility and aromatic content. In: THEISEL 2010 conference on thermo- and dynamic processes in diesel engines, Valencia, Spain, 14 17 September 2010, pp.409-420. Valencia: CMT-Motores Tèrmicos, Universitat Politècnìca de Valèncìa.

5. Kalghatgi G, Hildingsson L, Harrison AJ and Johansson B. Auto-ignition quality of gasoline fuels in partially premixed combustion in diesel engines. Proc Combust Inst 2011; 33: 3015-3021.

6. Li T, Okabe Y, Izumi H and Ogawa H. Dependence of ultra-high EGR low temperature combustion on fuel properties. SAE paper 2006-01-3387, 2006.

7. Schleyer GH, Duffy KP, Liechty MP et al. Effects of fuel property changes on heavy duty HCCI combustion. SAE paper 2007-01-0191, 2007.

8. Manente V, Johansson B and Tunestål P. Partially premixed combustion at high load using gasoline and ethanol, a comparison with diesel. SAE paper 2009-01-0944, 2009.

9. Manente V, Johansson B, Tunestål P and Canella W. Effects of different types of gasoline fuels on heavy duty partially premixed combustion. SAE paper 2009-01-2668, 2009.
10. Hanson R, Splitter D and Reitz R. Operating a heavyduty direct-injection compression-ignition engine with gasoline for low emissions. SAE paper 2009-01-1442, 2009.

11. Weall AJ and Collings N. Investigation into partially premixed compression ignition in a light duty multi cylinder engine: a study of low load and low speed operation. SAE paper 2007-01-4058, 2007.

12. Weall AJ and Collings N. Gasoline fuelled partially premixed compression ignition in a light duty multi cylinder engine: a study of low load and low speed operation. SAE paper 2009-01-1791, 2009.

13. Kalghatgi GT. Auto-ignition quality of practical fuels and implications for fuel requirements of future SI and HCCI engines. SAE paper 2005-01-0239, 2005.

14. Won H, Peters N, Tait N and Kalghatgi GT. Sufficiently premixed compression ignition of a gasoline-like fuel using three different nozzles in a diesel engine. Proc IMechE Part D: J Automobile Engineering 2012: 226(5); 698-708.

15. Leduc P, Dubar B, Ranini A and Monnier G. Downsizing of gasoline engine: an efficient way to reduce $\mathrm{CO}_{2}$ emissions. Oil Gas Sci Technol, Rev IFP 2003; 58(1): 115-127.

16. $\mathrm{Su} \mathrm{W}$, Lin $\mathrm{T}$ and Pei $\mathrm{Y}$. A compound technology for HCCI combustion in a DI diesel engine based on multipulse injection and the BUMP combustion chamber. SAE paper 2003-01-0741, 2003.

17. Mueller CJ, Martin GC, Briggs TE and Duffy K P. An experimental investigation of in-cylinder processes under dual-injection conditions in a DI diesel engine. SAE paper 2004-01-1843, 2004.

18. Dronniou N, Lejeune M, Balloul I and Higelin P. Combination of high EGR rates and multiple injection strategies to reduce pollutant emissions. SAE paper 2005-01-3726, 2005.

19. Carlucci P, Ficarella A and Laforgia D. Effects on combustion and emissions of early and pilot fuel injections in diesel engines. Int $J$ Engine Res 2005; 6(1): 43-60.

20. Mueller CJ, Piz WJ, Pickett LM et al. Effects of oxygenates on soot processes in DI diesel engines: experiments and numerical simulations. SAE paper 2003-01-1791, 2003. 